02 Royal Netherlands Institute for Sea Research

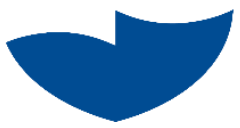

This is a postprint of:

van Soelen, E.E.; Kim, J.-H.; Ventura Santos, R.; Dantas, E.L.; Vasconcelos de Almeida, F.; Pinheiro Pires, J.; Roddaz, M. \& Sinninghe Damsté, J.S. (2017). A 30 Ma history of the Amazon River inferred from terrigenous sediments and organic matter on the Ceará Rise. Earth and Planetary Science Letters, 474, $40-48$

Published version: https://doi.org/10.1016/i.epsl.2017.06.025

Link NIOZ Repository: $\underline{w w w . v l i z . b e / n l / i m i s ? m o d u l e=r e f \& r e f i d=286584}$

[Article begins on next page]

The NIOZ Repository gives free access to the digital collection of the work of the Royal Netherlands Institute for Sea Research. This archive is managed according to the principles of the Open Access Movement, and the Open Archive Initiative. Each publication should be cited to its original source - please use the reference as presented.

When using parts of, or whole publications in your own work, permission from the author(s) or copyright holder(s) is always needed. 


\title{
A 30 Ma history of the Amazon River inferred from terrigenous sediments and organic matter on the Ceará Rise
}

\author{
Elsbeth E. van Soelena ${ }^{\mathrm{a},{ }^{*}, 1}$, Jung-HyunKima ${ }^{\mathrm{a}, 2}$, Roberto Ventura Santos ${ }^{\mathrm{b}}$, Elton Luiz Dantas ${ }^{\mathrm{b}}$, Fernanda \\ Vasconcelos de Almeida ${ }^{c}$, Juliana Pinheiro Pires ${ }^{\mathrm{c}}$, Martin Roddaz ${ }^{\mathrm{d}}$, Jaap S. Sinninghe Damstéae
}

a NIOZ Royal Netherlands Institute for Sea Research, Department of Marine Microbiology and Biogeochemistry, PO Box 59, 1790 AB Den Burg (Texel), The Netherlands

${ }^{\mathrm{b}}$ Universidade de Brasília (UnB), Instituto de Geociências, 70910-900 Brasília, DF, Brazil

${ }^{c}$ Universidade de Brasília (UnB), Instituto de Química, 70910-900 Brasília, DF, Brazil

${ }^{\mathrm{d}}$ Géosciences-Environnement Toulouse, Université de Toulouse, CNRS-IRD-OMP, 14 avenue Edouard Belin 31400, Toulouse, France

${ }^{\mathrm{e}}$ Utrecht University, Faculty of Geosciences, Department of Earth Sciences, PO Box 80.021, 3508 TA Utrecht, The Netherlands

* Corresponding author. E-mail address: evansoelen@gmail.com (E.E. van Soelen).

${ }^{1}$ Current address: University of Oslo, Department of Geosciences, Sem Sælands vei 1, 0371 Oslo, Norway.

${ }^{2}$ Current address: Korea Polar Research Institute, 26 Songdomirae-ro, Yeonsu-gu, Incheon 21990, South Korea

\begin{abstract}
The history of the Amazon River is a much-discussed subject, and the timing of the development of a transcontinental system in particular is a matter of some controversy, with estimations varying between the Early Miocene and the Pliocene or even the Pleistocene. To shed further light on this, we studied the sediment provenance of an Oligocene to Late Pleistocene marine sedimentary section from the Ceará Rise (ODP Site 925), a topographic high in the central Atlantic Ocean, using major element concentrations and Nd isotopic composition in 85 samples. In addition, the carbon isotopic composition of bulk organic matter and changes in the distribution of glycerol dialkyl glycerol tetraethers (GDGTs) were used to identify periods of increased river outflow. On the basis of these results, we suggest that the history of the development of the Amazon River is characterized by specific steps. During the late Oligocene/Early Miocene (30-18.3 Ma), the terrigenous mass accumulation rates (TARs) were high, and sediment and GDGT compositions suggest that a large river system existed, which at times received weathering products from a younger and probably Andean sediment source. A shift to a younger Andean sediment provenance after 8.7 Ma indicates that the Amazon River became permanently connected with the Andes. Between 18.3 and 4.5 Ma, TARs were generally low, and GDGTs were derived for the most part from in situ production in marine waters. Around 4.5 Ma, the river expanded, probably due to ongoing tectonic activity, and uplift in the Andes increased Andean rock erosion. This led to a strong increase in terrigenous sediment deposition and enhanced organic matter preservation on the Ceará Rise, and the delivery of terrestrial (both soil and riverine) branched GDGTs to the Ceará Rise.
\end{abstract}

Keywords: Ceará Rise, Amazon, Nd isotopes, GDGT 


\section{Introduction}

The Amazon River is one of the largest rivers in the world, both in terms of water and particulate matter discharge. The two Andean tributaries Solimões and Madeira combined are responsible for 95\% of the suspended matter that is delivered to the Atlantic Ocean on an annual basis, while only a small part is supplied by the cratonic tributaries of the Japurá, Negro, Trombetas, Tapajos, and Xingu rivers (e.g., Viers et al., 2008 and references therein). The geological history of the Amazon River is a much-discussed subject, and estimations on the timing of the development of a transcontinental system vary from the Late Miocene to the Late Pliocene (e.g., Campbell, 2010; Campbell et al., 2006; Figueiredo et al., 2010, 2009).

Large-scale paleo-geographical changes took place during the Neogene, which affected the drainage pattern in the Amazon basin. During the Early-Middle Miocene, a wetland system existed in the western Amazonas that was limited to the east by the Purus Arch, which temporarily acted as a barrier preventing transport from west to east. This barrier later became incised by the expanding river system in the Late Miocene, and a connection with the eastern Amazonas was established (e.g., Hoorn et al., 1995). The Iquitos Arch, which is located further to the west of the Solimões basin, was probably incised at a later stage, although estimations of the exact timing also vary here (e.g., Horbe et al., 2013; Roddaz et al., 2005a, 2005b) due to a lack of precise stratigraphic dating. The resulting increase in erosion and sediment transport from the Andes toward the east resulted in a substantial increase in sediment deposition near the Amazon mouth since either 11.8-10.5 Ma (Figueiredo et al., 2010, 2009) or 9.5-8.3 Ma (Gorini et al., 2014). The expanding river system also noticeably affected sedimentation on the Ceará Rise, an oceanic ridge east of the Amazon River mouth (e.g., Dobson et al., 2001; Heinrich and Zonneveld, 2013). In a recent study, Stewart et al. (2016) showed that runoff from the Amazon River influenced sedimentation on the Ceará Rise during the Oligocene-Miocene transition.

To improve our understanding the geological history of the Amazon River system, we have performed a sediment provenance study based on major element concentrations and the $\mathrm{Nd}$ isotopic composition of sediments deposited on the Ceará Rise since the late Oligocene. This Rise is an interesting study location because of its relatively close proximity to the Amazon River mouth (Fig. 1), while at the same time it is less sensitive to sea level fluctuations than the Amazon fan. Sm-Nd isotope values and elemental composition of Ceará Rise sediments are compared with rocks from different sedimentary basins and volcanic and cratonic sediment sources in the Amazon basin. The large difference in age between the Andean volcanic structures and the cratonic material make $\mathrm{Nd}$ isotopes a valuable and commonly used tool for provenance studies in the Amazon basin (e.g., Roddaz et al., 2005b). In addition to the inorganic geochemistry, we have also studied the organic matter that is preserved in the Ceará Rise sediments. Specific lipid biomarkers provide information on the organic matter sources, which allows for identification of periods during which more terrestrial-derived organic matter, indicating Amazon River runoff, was able to reach the Rise.

\section{Background}

\subsection{Study area: Ceará Rise}

A rise formed about $80 \mathrm{Ma}$ as a result of volcanism at the mid-Atlantic Ridge (Kumar and Embley, 1977). Spreading of the ridge subsequently divided this volcanic pile into two parts, and the western part is known as the Ceará Rise (Kumar and Embley, 1977). Since then, the Ceará Rise has drifted westwards, while its relative position with respect to the South American margin has not changed substantially (Curry et al., 1995). The nature of sediments that cover the Ceará Rise has changed significantly since the early Miocene. Up to that time, the Ceará Rise was covered mainly by calcareous and siliceous pelagic sediments. Since the early Miocene, however, a large influx of terrigenous material derived from the Brazilian margin has been deposited at the western part of the Ceará Rise (Curry et al., 1995; Kumar and Embley, 1977).

\section{2. $N d$ in provenance studies}

The $\mathrm{Nd}$ isotopic composition of sedimentary rocks is widely used in provenance studies because the $\mathrm{Nd}$ is not fractionated by sedimentary and post-depositional processes (e.g., McLennan et al., 1993 and references therein). The most important process that fractionates $\mathrm{Nd}$ from $\mathrm{Sm}$ is the melting of the mantle to form plutonic rocks that are more differentiated (DePaolo and Wasserburg, 1976). Available studies have shown that the sediments transported by the different Amazonian rivers can be distinguished based on their Nd isotopic compositions (e.g., Allègre et al., 1996; Bouchez et al., 2011; Viers et al., 2008). While cratonic-derived river sediments are characterized by low radiogenic $\mathrm{Nd}$ isotopic composition with $\varepsilon \mathrm{Nd}(0)$ values $<-15$ (Allègre et al., 1996; Bayon et al., 2015), suspended particulate material (SPM) derived from the Amazon Andean river has $\varepsilon N d(0)$ values $>-12.1$ (Viers et al., 2008). For instance, the Solimões River has higher SPM $\varepsilon N d(0)$ values $(-8.9$ to -9.9$)$ than those of the Madeira River $(-10.8$ to -12.1$)$. Present-day sediments of the Amazon delta have $\varepsilon N d(0)$ values between -10.5 and -10.7 (Bayon et al., 2015).

The $\mathrm{Nd}$ isotopic composition of past sediments have been used to determine the onset of the transcontinentalization of the Amazon River by constraining the first arrival of Andean sediments in the Amazon fan (Figueiredo et al., 2009), to determine the provenance of Amazonian sediments (Horbe et al., 2013), and to 
reconstruct the Neogene paleo-drainage of Western Amazonia (Roddaz et al., 2005b). Past cratonic-derived sedimentary rocks have $\varepsilon \mathrm{Nd}(0)$ values between -14.5 and -20 , and Andeanderived sediments have $\varepsilon \mathrm{Nd}(0)$ values >-13.8 (Figueiredo et al., 2009; Horbe et al., 2013; Roddaz et al., 2005b). In Colombia, the $\varepsilon N d(0)$ cutoff value of -12.7 has been used to distinguish between Andean and cratonic-derived sedimentary rocks (Nie et al., 2012).

\section{3. $\delta^{13} C_{T O C}$ and GDGTs to track sources of organic matter}

The organic matter that is preserved in the Ceará Rise sediments consists of a mixture of marine organic matter produced in situ and terrestrial organic matter that is transported from the South American continent into the Atlantic Ocean. One way to evaluate the relative contribution of marine- versus terrestrialderived organic matter is to examine the $\delta^{13} \mathrm{C}$ values of bulk organic matter $\left(\delta^{13} \mathrm{C}_{\mathrm{TOC}}\right)$. Currently, suspended matter in the Amazon River contains substantial amounts of soil-derived organic matter, resulting in a $\delta^{13} \mathrm{C}$ value of around $-29.3 \%$ (Kim et al., 2012). Past changes in the carbon isotopic composition of bulk organic matter in the Ceará Rise sediments is (in part) controlled by the relative contributions of terrestrial versus marine organic matter, although the isotopic composition of total dissolved $\mathrm{CO}_{2}$ in the ocean might have also been heavier earlier in the Cenozoic (Ohkouchi and Wado, 1997), and the degree of isotopic fraction by marine phytoplankton was also variable.

Lipids preserved in the Ceará Rise sediments may contain further clues about if and when river water

from the South American continent reached the Rise. In particular, glycerol dialkyl glycerol tetraethers (GDGTs) can be useful, as they are produced in both terrestrial and aquatic environments. Crenarchaeol, an isoprenoid GDGT, is produced predominantly by Thaumarchaeota in the marine environment (Sinninghe Damsté et al., 2002), but it is also produced in freshwater environments (e.g., Powers et al., 2004) and in soils (e.g., Weijers et al., 2007). Branched GDGTs (brGDGTs) are predominantly produced in situ in soils (e.g., Weijers et al., 2007), lakes (e.g., Tierney et al., 2010), and rivers (e.g., Zell et al., 2013b, 2013a) but also appear in the marine environment (Peterse et al., 2009; Sinninghe Damsté, 2016). Previous studies have shown that the relative contributions of different groups of GDGTs in marine sediments can provide indications of the relative contribution of terrestrial-derived organic matter versus in situ production (Hopmans et al., 2004; Sinninghe Damsté, 2016). Hence, changes in the different groups of GDGTs in the Ceará Rise sediments can be indicative of changes in runoff and thus for changes in the paleogeography of the Amazon River

\section{Material and methods}

3.1. ODP site 925

ODP site 925 is located around $4 \circ \mathrm{N}$ and $43^{\circ} \mathrm{W}$, at the western border of the Ceará Rise (Fig. 1). The core was drilled approximately $800 \mathrm{~km}$ from the mouth of the Amazon River and at a depth of 3,040 m below sea level. Selected material for this study is derived from Hole 925A (Oligocene-Middle Miocene) and Hole 925B (Middle Miocene-Pleistocene) (Curry et al., 1995). In total, 85 sediment samples were collected over a range of 0-650 m below seafloor (mbsf), typically with 3-10 m sample intervals. Samples were collected from the same cores as studied by Dobson et al. (2001), but the resolution of our sampling was substantially higher. The age model is based on calcareous nanoplankton events in Holes 925A and 925B (in Curry et al., 1995, available at the ODP Janus web database) following the GPTS 2012 time scale (Gradstein et al., 2012).

\subsection{X-ray fluorescence (XRF) analyses}

Elemental analysis of individual samples was done with X-ray fluorescence (XRF) at the Instituto de Geociências at the Universidade de Brasília (UnB). Organic matter was removed from precisely weighed, freezedried, and homogenized sediments using loss of ignition (LOI) at $1000^{\circ} \mathrm{C}$ for $2 \mathrm{~h}$. Pellets were made by adding Spectromelt 10 (di-lithium tetraborate) resin to precisely weighed samples. XRF analyses were performed using an XRF spectrometer (Priumus II-RIGAKU) with 25 min of analysis time per sample. Cluster analysis was done on the elements of the terrigenous fraction, which we defined as the total fraction minus the carbonates. Clusters were identified by constrained agglomerative hierarchical clustering, using the unweighted pair-group average (UPGMA) and Euclidean distance via the software PAST (Hammer et al., 2001).

\subsection{Neodymium (Nd) and Samarium (Sm) isotope analyses}

$\mathrm{Nd}$ and $\mathrm{Sm}$ analyses were done at the Instituto de Geociências at UnB. Preparation and analyses of Sm and $\mathrm{Nd}$ isotopes were performed following the procedures described by Gioia and Pimentel (2000). Briefly, an internal standard was added (a mix of Sm and Nd enriched in ${ }^{149} \mathrm{Sm}$ and ${ }^{150} \mathrm{Nd}$ ) to approximately $100 \mathrm{mg}$ of homogenized sediments in a Teflon container. The material was digested using different acid attacks, including $\mathrm{HNO}_{3}, \mathrm{HF}_{\text {, }}$ and $\mathrm{HCl}$. An aliquot of each sample was used for $\mathrm{Sm}$ and $\mathrm{Nd}$ isotope analyses. Fractions containing $\mathrm{Sm}$ and $\mathrm{Nd}$ were loaded onto Re evaporation filaments of a double filament assembly and analyzed on a Finnigan TRITON multi-collector mass spectrometer in static mode. International rock standards BCR-1 and BHVO-1 were used to evaluate the isotopic analyses of $147 \mathrm{Sm} / 144 \mathrm{Nd}$ and $143 \mathrm{Nd} / 144 \mathrm{Nd}$ ratios, with uncertainties generally better than 
$\pm 0.1 \%(2 \sigma)$ and $0.005 \%(2 \sigma)$, respectively (Dantas et al., 2009). Fractional deviations of $\mathrm{Sm} / \mathrm{Nd}(\mathrm{fSm} / \mathrm{Nd})$ and $\mathrm{Nd} / \mathrm{Nd}(\varepsilon \mathrm{Nd}(0))$ from CHUR were calculated following DePaolo and Wasserburg (1976).

\subsection{Bulk organic geochemical analyses}

Analyses of total organic carbon (TOC) and the stable carbon isotopic composition of TOC $\left(\delta^{13} \mathrm{C}_{\mathrm{TOC}}\right)$ were performed at the NIOZ. Homogenized samples (ca. $0.3 \mathrm{~g}$ ) were weighed and decalcified by adding about $35 \mathrm{~mL}$ of $4 \mathrm{M}$ hydrochloric acid $(\mathrm{HCl})$. After shaking overnight (for ca. $12 \mathrm{~h}$ ), the $\mathrm{HCl}$ was removed, and the $\mathrm{pH}$ was neutralized by washing the sediments with ultrapure distilled water. Samples were subsequently freeze-dried and reweighed. An elemental analyzer (Flash EA 1112 series) was used to determine the TOC content (expressed as $\mathrm{wt} \%)$ and the $\delta^{13} \mathrm{C}_{\mathrm{TOC}}$. Isotope values were calibrated to an in-house benzoic acid standard $\left(\delta^{13} \mathrm{C}=-28.1 \%\right.$ with respect to Vienna Pee Dee Belemnite (VPDB), calibrated on NBS-22). The analytical error was typically

\subsection{Lipid analyses}

Freeze-dried and homogenized sediments $(0.5-12 \mathrm{~g})$ were extracted at the Instituto de Geociências at UnB using an ultrasonic bath. A solvent mixture of dichloromethane (DCM) and methanol (MeOH) $(2: 1, v: v)$ was added to each sample, and the samples were placed in an ultrasonic bath for $5 \mathrm{~min}$ and then centrifuged, after which the solvent was decanted. This procedure was repeated four times, after which solvent fractions were combined and solvents were evaporated, resulting in a total lipid extract (TLE). Traces of water were removed using a small column (Pasteur pipette) with $\mathrm{Na}_{2} \mathrm{SO}_{4}$. The TLE was subsequently split into three fractions of different polarity using small columns (Pasteur pipettes), with activated aluminum oxide and the following solvent mixtures as eluents: dichloromethane (DCM):hexane (9:1,v:v), DCM:hexane $(1: 1, v: v)$, and DCM:MeOH $(1: 1, v: v)$ to collect fractions I-III, respectively. Fraction III contained branched and isoprenoid GDGTs. For quantification purposes, a $\mathrm{C}_{40}$ GDGT standard was added to Fraction III. This fraction was then dissolved in a mixture of hexane:isopropanol $(99: 1, v: v)$ and filtered over a $0.45 \mu \mathrm{m}$ PTFE filter. GDGTs were analyzed at NIOZ, using high performance liquid chromatography - atmospheric pressure positive ion chemical ionization - mass spectrometry in selected ion monitoring mode, following the procedure described in Hopmans et al. (2016).

\section{Results}

\subsection{Age model and mass accumulation rates}

Our age model differs slightly from the one published in Dobson et al. (2001), since we used the new GPTS 2012 time scale of Gradstein et al. (2012). In the intervals between 17.0 and 14.5 Ma and 23.0 and 20.0 Ma, the age model gives ages that are up to 0.5 Myr younger than those previously used by Dobson et al. (2001). Mass accumulation rates (MARs) were calculated based on the new age model and XRF and density data (available at the ODP Janus web database). Terrigenous mass accumulation rates (TARs) vary between 0.3 and $1.8 \mathrm{~g} \mathrm{~cm}-2$ kyr-1 (Fig. 2A). TARs drop sharply from 1.3 to $0.3 \mathrm{~g} \mathrm{~cm}-2 \mathrm{kyr}-1$ after $18.3 \mathrm{Ma}$, followed by a gradual increase with second order variability until around 11.3 Ma. Between 10 and 4.5 Ma, TARs are relatively low, then they increase from 4.5 Ma to the present.

\subsection{Bulk sediment parameters}

$\mathrm{CaCO} 3$ content (Fig. 2B) varies between $20 \%$ and $87 \%$; in the majority of the sediments, $\mathrm{CaO}$ is the dominant element, followed by $\mathrm{SiO}_{2}(10-45 \%), \mathrm{Al}_{2} \mathrm{O}_{3}$ (3.5-18.5\%), and $\mathrm{Fe}_{2} \mathrm{O}_{3}$ (1.5-9.5\%) (Supplementary Table S1). There is a positive correlation between the content of $\mathrm{SiO}_{2}, \mathrm{Al}_{2} \mathrm{O}_{3}, \mathrm{Fe}_{2} \mathrm{O}_{3}$, and $\mathrm{TiO}_{2}$ and a negative correlation of the contents of these elements with that of $\mathrm{CaO}$. Ti/Ca and $\mathrm{Al} / \mathrm{Si}$ ratios are presented in Figs. $2 \mathrm{C}$ and $2 \mathrm{D}$. $\mathrm{Ti} / \mathrm{Ca}$ ratios shift toward lower values after 18.3 Ma and increase after 4.5 Ma. Between 18.3 and 4.5 Ma, the ratio is generally low, although there are some variabilities, and values can be higher, especially before $12.4 \mathrm{Ma}$. $\mathrm{Al} / \mathrm{Si}$ ratio is low at $18.3 \mathrm{Ma}$, then starts to increase, and values become much higher after 12.4 Ma. After 8.7 Ma, the $\mathrm{Al} / \mathrm{Si}$ ratio decreases again to values similar to those found in the period between 18.3 and $12.4 \mathrm{Ma}$. Cluster analyses of the terrigenous fraction identified three clusters: 1) $29.9-12.8 \mathrm{Ma}, 2$ ) $12.8-8.7 \mathrm{Ma}$, and 3) $8.7-0.1$ Ma (Fig. S1).

\subsection{Nd isotopes}

$\mathrm{Nd}$ concentrations vary between 6.9 and $32.6 \mathrm{ppm}$ along the studied section and are positively correlated with the content of $\mathrm{SiO} 2$ and $\mathrm{A} 12 \mathrm{O} 3$ (Supplementary Table S2). The $\mathrm{Nd}$ isotopic composition varies between 0.511606 and 0.512083 , corresponding to $\varepsilon N d(0)$ values that range between -20.1 and -10.8 . Three main intervals indicated by the $\varepsilon \mathrm{Nd}(0)$ values may be defined along the core (Fig. $2 \mathrm{E}$ ). The lower interval is between 30 and $18.3 \mathrm{Ma}$, in which the $\varepsilon \mathrm{Nd}(0)$ values are variable. $\varepsilon \mathrm{Nd}(0)$ values of the intermediate interval between 18.3 and 8.7 Ma vary between -12 and -19 . After $8.7 \mathrm{Ma}, \varepsilon \mathrm{Nd}(0)$ values first become gradually less negative, while varying between -15 and -11 , and from 4.5 Ma onwards, values become more stable and vary between -13 and -10 . 


\subsection{Bulk organic matter and biomarker lipids}

The TOC content (Fig. 3A) along the core varies between 0.04 and $0.38 \mathrm{wt} \%$. Around $18.3 \mathrm{Ma}$, there is an abrupt shift from relatively high values (between 0.1 and $0.3 \mathrm{wt} \%)$ to lower values $(<0.1 \mathrm{wt} \%)$. The TOC content stays low (between 0.03 and $0.08 \mathrm{wt} \%$ ) until $4.5 \mathrm{Ma}$, although intervals with higher values occur periodically (up to $0.23 \mathrm{wt} \%$ ). $\delta^{13} \mathrm{C}_{\text {TOC }}$ values (Fig. $3 \mathrm{~B}$ ) range between -20.5 and $-28.3 \%$, and values are variable throughout the core. Between 30 and $18.3 \mathrm{Ma}$, values show an increasing trend from -26 to $-23 \%$. From $4.5 \mathrm{Ma}$ onwards, values become on average less negative, and they stabilize between -21 and $-22 \%$.

Concentrations of crenarchaeol (Fig. 3C) and brGDGTs (Fig. 3D) decrease after $18.3 \mathrm{Ma}$, and values stay relatively low until $4.5 \mathrm{Ma}$, although periodically higher values can be found, especially between 18.3 and $12 \mathrm{Ma}$. Lipid concentrations, especially brGDGTs, increase after 4.5 Ma. Ratios between the different types of GDGTs reveal marked changes around 18.3, 12.4, and after 4.5 Ma. The branched and isoprenoid tetraether (BIT) index increases after 18.3 Ma and again after 12.4 Ma. The fractional abundance of tetramethylated brGDGTs (\%tetra) shows relatively lower values between 18.3 and $4.5 \mathrm{Ma}$, while the weighted average number of cyclopentane moieties of the predominant tetramethylated brGDGTs (\#ringstetra) is relatively high in this period.

\section{Discussion}

\subsection{Sedimentation on the Ceará Rise}

The Ceará Rise lies approximately $800 \mathrm{~km}$ off the coast of Brazil, directly in line with the outflow of the Amazon River. The terrigenous component of the Ceará Rise sediments is therefore likely predominantly derived from riverine input. Aeolian dust from northern Africa, which is an important contributor of phosphorus for the Amazon rainforest (Yu et al., 2015), may be a secondary contributor of terrigenous matter. To evaluate the contribution of this dust to the sediments on the Ceará Rise, a comparison of the main terrigenous elements ( $\mathrm{Si}, \mathrm{Al}$, and $\mathrm{Fe}$ ) in the core with possible sources of terrigenous sediments was performed (Fig. 4). Sahara dust is enriched in Si compared to both the riverderived and Ceará Rise sediments, which suggests that the effect of dust on the total composition of the terrigenous fraction of the Ceará Rise sediments is small. Instead, the Ceará Rise sediments represent a mixture of material with dominant Andean (Madeira, Solimões) and cratonic sources (e.g., Negro). Sedimentation on the Ceará Rise thus predominantly reflects changes in runoff from the South American continent.

Cluster analysis of XRF data on the terrigenous sediment (all major elements except Ca) defines the interval between 12.4-8.7 Ma separately and is characterized by high Al/Si ratios (Fig. 2D) and low TARs (Fig. $2 \mathrm{~A}$ ). The $\mathrm{Al} / \mathrm{Si}$ ratio can be considered to represent grain size, as $\mathrm{Al}$ is dominant in the clay fraction and $\mathrm{Si}$ is the main constituent of quartz, which is the principal mineral in the sand fraction (Bouchez et al., 2011; Roddaz et al., 2014). Heinrich and Zonneveld (2013) found indications for pulses of North Atlantic deep water (NADW) reaching the Ceará Rise from 12.4 Ma onwards, coinciding with the increase in $\mathrm{Al} / \mathrm{Si}$ in the Ceará Rise sediments. Shoaling, and eventually closing of the Panama Isthmus, caused a reversion of the Brazil current, which flows parallel to the Brazilian coastline (e.g., Heinrich and Zonneveld, 2013). As this likely affected the direction of the out- flow of the Amazon River, it is possible that lower accumulation rates in the mid-Miocene are a consequence of a (temporary) redirection of sediments toward another deposition area.

\subsection{Provenance of the Ceará Rise sediments}

Fig. $5 \mathrm{~B}$ shows $\varepsilon \mathrm{Nd}(0)$ and $\mathrm{fSM} / \mathrm{Nd}$ values of the two main source areas in South America (the Precambrian craton and Andean igneous rocks) together with current data from the Andean foreland sediments and the Amazon River. All data from the Ceará Rise sediments plot between the two main source areas, indicating that, at all times, they represent a mixture between old Precambrian (cratonic) and younger sedimentary sources. The clusters that are established based on the inorganic composition of the terrigenous fraction also can be differentiated based on $\varepsilon \mathrm{Nd}(0)$ data (Figs. 5A and B). Cluster 1 (29.9-12.8 Ma) shows a higher variability in $\varepsilon \mathrm{Nd}(0)$, with values ranging between -19 and -12 . Cluster $2(12.8-8.7 \mathrm{Ma})$, with the higher $\mathrm{Al} / \mathrm{Si}$ values, overlaps with the cluster $1(8.7-0.1 \mathrm{Ma})$, but it is biased toward more negative $\varepsilon N d(0)$ values, suggesting a greater influence of the craton. Values found in clusters 1 and 2 are comparable to those found in the modern Congo River, which drains similar Precambrian terranes as those exposed in the South American craton and thus can be considered to be a cratonic river (Bayon et al., 2015). Perhaps more surprising is the presence of relatively young sediments in cluster 1 , with values comparable to those found in cluster 3. At 18.3 Ma, sediments have a $\varepsilon \operatorname{Nd}(0)$ value of -12.1 , suggesting the input of younger detritus onto the Ceará Rise previous to the establishment of a transcontinental system. This value is close to present-day Madeira River suspended sediment, Amazon River mouth suspended material, and Amazon floodplain sediments (Fig. 5), and it is comparable only with the Ceará Rise sediments deposited after 4.5 Ma. This change toward a less negative $\varepsilon \operatorname{Nd}(0)$ value might indicate that a transcontinental connection temporarily existed before the Middle Miocene times. Elemental data published by Dobson et al. (2001) indicate a dominant Archean shield source for Eocene until approximately 16.5 Ma. However, within this interval, there are periods (e.g., 40-36.5 Ma and 34-31 Ma) 
during which changes in elemental composition suggest periodic input from distal and younger terrains (Dobson et al., 2001). These authors did not find evidence for a younger sediment source between 20 and 16.5 Ma.

However, this might be explained by the fact that we only observed evidence for Andean-derived sediments for a short interval around 18.3 Ma, an interval that was not included in the lower-resolution dataset of Dobson et al. (2001).

Relatively high TAR and low $\mathrm{CaCO} 3$ at this time also suggest an increase in river runoff, which would support the existence of a large river system. Furthermore, the northern Peruvian Eastern Cordillera and Subandean Zone, as well as the Colombian Eastern Cordillera, started to form in the Late Oligocene-Early Miocene (e.g., Eude et al., 2015; Mora et al., 2013, 2010). These uplifts may have caused a temporary transcontinental connection to exist and are the most likely explanation for the observed $\varepsilon \operatorname{Nd}(0)$ values. In this scenario, the Purus Arch, which is supposed to be a topographic barrier preventing the arrival of Andean sediments into the Atlantic Ocean during the Middle Miocene (Figueiredo et al., 2010, 2009), would be temporarily overfilled by Andean-derived sediments.

The second cluster overlaps with a sedimentary interval that is defined by Dobson et al. (2001) as a complex chemical composition, showing characteristics of both Andean and highly weathered Phanerozoic rock sources. Still, $\varepsilon \mathrm{Nd}(0)$ values in this interval are between -15 and -18 (Fig. $2 \mathrm{E}$ ), and $\mathrm{Nd}$-model ages indicate a sediment source between 1.67-1.91 Ga (Supplementary Table S1), which would be a dominant cratonic source. The abrupt drop in $\mathrm{Al} / \mathrm{Si}$ ratios around $8.7 \mathrm{Ma}$ (Fig. 2D) and shift toward less negative $\varepsilon \mathrm{Nd}(0)$ values coincides with the initiation of the Amazon fan between 9.5-8.3 Ma (Gorini et al., 2014) (Fig. 6). This is in agreement with several studies showing that transcontinentalization became permanent around the Late Miocene (Dobson et al., 2001; Figueiredo et al., 2010, 2009).

The youngest cluster (3) has less negative $\varepsilon \mathrm{Nd}(0)$ values and partly overlaps with Andean foreland sediments (Fig. 5B), which makes it more comparable to present-day Amazon River sediments. Within cluster 3 , a change takes place around 4.5 Ma when $\varepsilon \mathrm{Nd}(0)$ values become less negative (Fig. 2), while TARs strongly increase at the same time. Dobson et al. (2001) also found an increase in terrigenous material input during the Pliocene, and they conclude that the enormous amount of discharge from the Amazon River has only occurred since the Pliocene. Campbell et al. (2006) and Horbe et al. (2013) argue that the Amazon River system expanded to its present architecture only during the Pliocene or even the Pleistocene. Our data supports a change in the river system, although this could result from both an expansion of the discharge area and an overall increase in sediment input from the Andes due to ongoing tectonic uplift and subsequent increase in erosion in this area (e.g., Eude et al., 2015; Mora et al., 2010; Oncken et al., 2006). In Figs. 5A and 5B, the Ceará Rise sediments younger than 4.5 Ma show strong affinities with modern suspended matter in the Madeira River and also with Amazon floodplain sediments.

\subsection{Organic matter sources and biomarker signals}

The $813 \mathrm{CTOC}$ record shows a general trend from more depleted values $(-26 \%)$ during the late Oligocene to less depleted values $(-21 \%$ ) toward the present (Fig. 3B). Although preferential preservation of the more resistant terrestrial OM may have affected the $\delta^{13} \mathrm{C}_{\mathrm{TOC}}$ signal (Prahl et al., 1997), it is unlikely that changes in preferential preservation during diagenesis can explain the observed long-term shift in $\delta^{13} \mathrm{C}_{\mathrm{TOC}}$ of about $3-4 \%$ (Ohkouchi and Wado, 1997). Thus, the more negative values throughout the record, but especially after 2 Ma, indicate a relatively larger contribution of marine-derived organic matter. Increased runoff from the Amazon River would not only increase the export of terrestrial organic matter but also directly affect the primary productivity in the Atlantic Ocean by supplying large amounts of nutrients. The less negative values in the upper part of the record are therefore a likely consequence of increased runoff and indicative of the existence of a large river system.

The BIT index, a ratio between acyclic brGDGTs and crenarchaeol, shows increasing values around 18.3 Ma and again after $12 \mathrm{Ma}$ (Fig. 3E). Originally, the BIT index was formulated to trace the input of terrestrial-derived organic matter in marine environments (Hopmans et al., 2004). In open marine environments, values are typically low, whereas in river fans, values typically decrease in a seaward direction (Hopmans et al., 2004). The high BIT values after $12 \mathrm{Ma}$ could thus be interpreted to represent a high river influence. However, these high BIT values $(>0.7)$ coincide with low brGDGT and crenarchaeol concentrations and are thus unlikely to reflect high terrestrial influence by riverine delivery of brGDGTs at this time. Instead, the BIT index is primarily controlled by changes in concentration of crenarchaeol (Fig. 3C), and changes in concentration of brGDGTs (Fig. 3D) are less influential. Crenarchaeol concentrations are highest between 30 and 18 Ma and after 4.5 Ma. Since crenarchaeol is mainly produced in the marine water column, these high concentrations are likely a direct consequence of high nutrient availability and thus indicative of the existence of a large river system. In the modern Amazon River, GDGTs in suspended particulate matter show complex mixtures of branched and isoprenoid GDGTs, which originate from soils and in situ production in the river (Zell et al., 2013a, 2013b). The fractional abundance \%tetra is dominant in soils $(>90 \%)$ and riverbanks and riverine suspended particulate matter (>70\%) (Zell et al., 2013b) and has been found in variable, but generally lower, abundances in shelf and fan suspended particulate matter and surface sediments (Zell et al., 2014). In the Ceará Rise record, \%tetra 
increases after 4.5 Ma. In this period, the GDGTs with cyclopentane rings built into their structure (\#ringstetra) had low values. This index was found to have higher values in sediments with increasing distance from the mouths of rivers (Sinninghe Damsté, 2016), and high values indicate in situ production in the marine environment (Peterse et al., 2009). Thus, high concentration of brGDGTs, in combination with high \%tetra and low in situ production (\#ringstetra), are indicative of increased terrestrial-derived organic matter reaching the Ceará Rise. River in- fluence on the Ceará Rise is especially large after 4.5 Ma. The river system must have increased its outflow around this time, probably by expansion in the upper Amazon area, since the change in sediment provenance also indicates an increase in the erosion and transport of Andean-derived material (Fig. 2). Between 30 and $18.3 \mathrm{Ma}$, brGDGT concentrations were also relatively high, although not as high as in the last 4.5 Ma (Fig. 3D). The combination with high \%tetra and a low \#ringstetra also indicates that a large river system existed during the late Oligocene to the early Miocene. Since at this time the river was not (or only at times) connected with the Andes, this river must have mostly drained the eastern part of the Amazon basin.

After 18.3 Ma, and especially between 12.4 and 8.7 Ma, a high \#ringstetra and a low \%tetra indicate little river influence at the Rise. TARs in this period were low, and only fine sediments reached the Ceará Rise (Figs. 2A and 2D). Around 12.4 Ma, the Central American Seaway, which allowed NADW to flow toward the Pacific, was sufficiently closed to force NADW into the South Atlantic Ocean, which consequently also changed the flow direction of the Brazil Current from SE to NW (Heinrich and Zonneveld, 2013; Nisancioglu et al., 2003) (see Fig. 6). The changes in flow direction of the major current in front of the coastline of Brazil likely affected sedimentation on the Ceará Rise. It is possible that less terrigenous sediment reached the Ceará Rise between 12.4 and $8.7 \mathrm{Ma}$ because the outflow of the river (temporarily) had a different direction and most of the (coarser-grained) sediment settled on a different location.

\section{Conclusions}

The main conclusions from this study are:

- During the late Oligocene/Early Miocene, a large river system existed, and high amounts of runoff transported sediments and terrestrial organic matter to the Ceará Rise. The river at this time had a mainly cratonic source, although variable $\varepsilon \mathrm{Nd}(0)$ values suggest a younger sediment source periodically contributed to the sediments. At $18.3 \mathrm{Ma}$, the $\varepsilon \mathrm{Nd}(0)$ value indicates a dominant input from a young sediment source, which can only be of Andean origin.

- During the Middle to Late Miocene, the low MARs indicate a change in the outflow of the river. Changes in ocean currents related to shallowing and eventually closing of the Panama Sill may have redirected the river outflow, which resulted in smaller amounts of suspended matter reaching the study site.

- After 8.7 Ma, sediment provenance permanently changed toward a younger source, indicating that a transcontinental connection between the Andes and the Atlantic Ocean was established. In addition, MARs strongly increased after 4.5 Ma, and there is an increase in the relative contribution of Andean derived erosive material to the total suspended matter in the river outflow.

- Our data thus indicates that the onset of transcontinentalization was not a single event, since a temporary supply of Andean sediments may have reached the Ceará Rise before the Late Miocene.

\section{Acknowledgements}

We acknowledge Andrés Mora and Maarten Lupker for providing insightful comments on an earlier version of this manuscript. We thank Jeane Grasyelle, Iris Dias, Rachel Bezerra and other analysts and students working at the Geochronology Laboratory of the University of Brasília for help with the Sr and Nd analyses. We also like to thank Denise Dorhout, Marianne Baas, Monique Veenstra, Angelique Mets, Jort Ossebaar, and Kevin Donkers for analytical assistance at the NIOZ. This research was partly funded by the joint Brazilian-European facility for climate and geodynamic research on the Amazon River Basin sediment (CLIM-AMAZON) project. The research leading to these results has also received funding from the European Research Council under the European Union's Seventh Framework Program (FP7/2007-2013)/ERC grant agreement No. [226600]. JSSD is supported by the Netherlands Earth System Science Centre (NESSC), financially supported by the Ministry of Education, Culture and Science (OCW) 024.002.001.

\section{References}

Allègre, C.J., Dupré, B., Négrel, P., Gaillardet, J., 1996. Sr-Nd-Pb isotope systematics in Amazon and Congo River systems: constraints about erosion processes. Chem. Geol. 131, 93-112. http://dx.doi.org/10.1016/0009-2541(96)00028-9.

Bayon, G., Toucanne, S., Skonieczny, C., André, L., Bermell, S., Cheron, S., Dennielou, B., Etoubleau, J., Freslon, N., Gauchery, T., Germain, Y., Jorry, S.J., Ménot, G., Monin, L., Ponzevera, E., Rouget, M.-L., Tachikawa, K., Barrat, J.A., 2015. Rare earth elements and neodymium isotopes in world river sediments revisited. Geochim. Cosmochim. Acta 170, 17-38. http://dx.doi.org/10.1016/j.gca. 2015.08.001. 
Bouchez, J., Gaillardet, J., France-Lanord, C., Maurice, L., Dutra-Maia, P., 2011. Grain size control of river suspended sediment geochemistry: clues from Amazon River depth profiles. Geochem. Geophys. Geosyst. 12, Q03008. http://dx.doi.org/ 10.1029/2010GC003380.

Campbell, K.E., 2010. Late Miocene onset of the Amazon River and the Amazon deep-sea fan: evidence from the Foz do Amazonas Basin: comment. Geology 38, e212. http://dx.doi.org/10.1130/G30633C.1.

Campbell, K.E., Frailey, C.D., Romero-Pittman, L., 2006. The Pan-Amazonian Ucayali Peneplain, late Neogene sedimentation in Amazonia, and the birth of the modern Amazon River system. Palaeogeogr. Palaeoclimatol. Palaeoecol. 239, 166-219. http://dx.doi.org/10.1016/j.palaeo.2006.01.020.

Collins, J.A., Govin, A., Mulitza, S., Heslop, D., Zabel, M., Hartmann, J., Röhl, U., Wefer, G., 2013. Abrupt shifts of the Sahara-Sahel boundary during Heinrich stadials. Clim. Past 9, 1181-1191. http://dx.doi.org/10.5194/cp-9-1181-2013.

Cordani, U.G., Sato, K., 1999. Crustal evolution of the South American Platform, based on Nd isotopic systematics on granitoid rocks. Episodes 22, 167-173.

Curry, W.B., Shackleton, N.J., Richter, C., et al. (Eds.), 1995. Proc. Ocean Drill. Program, Initial Rep., vol. 154. Ocean Drilling Program.

Dantas, E.L., de Alvarenga, C.J.S., Santos, R.V., Pimentel, M.M., 2009. Using Nd isotopes to understand the provenance of sedimentary rocks from a continental margin to a foreland basin in the Neoproterozoic Paraguay Belt, Central Brazil. Precambrian Res. 170, 1-12. http://dx.doi.org/10.1016/j.precamres.2008.11.005.

DePaolo, D.J., Wasserburg, G.J., 1976. Nd isotopic variations and petrogenetic models. Geophys. Res. Lett. 3, 249-252. http://dx.doi.org/10.1029/GL003i005p00249.

Dobson, D.M., Dickens, G.R., Rea, D.K., 2001. Terrigenous sediment on Ceara Rise: a Cenozoic record of South American orogeny and erosion. Palaeogeogr. Palaeoclimatol. Palaeoecol. 165, 215-229. http://dx.doi.org/10.1016/S0031-0182(00)00161-9.

Eude, A., Roddaz, M., Brichau, S., Brusset, S., Calderon, Y., Baby, P., Soula, J.-C., 2015. Controls on timing of exhumation and deformation in the northern Peruvian eastern Andean wedge as inferred from lowtemperature thermochronology and balanced cross section. Tectonics 34, 2014TC003641. http://dx.doi.org/ 10.1002/2014TC003641.

Figueiredo, J., Hoorn, C., van der Ven, P., Soares, E., 2010. Late Miocene onset of the Amazon River and the Amazon deep-sea fan: evidence from the Foz do Amazonas Basin: reply. Geology 38, e213. http://dx.doi.org/10.1130/G31057Y.1.

Figueiredo, J., Hoorn, C., van der Ven, P., Soares, E., 2009. Late Miocene onset of the Amazon River and the Amazon deep-sea fan: evidence from the Foz do Amazonas Basin. Geology 37, 619-622. http://dx.doi.org/10.1130/G25567A.1.

Gioia, S.M.C.L., Pimentel, M.M., 2000. The Sm-Nd isotopic method in the geochronology laboratory of the University of Brasília. An. Acad. Bras. Ciênc. 72, 219-245. http://dx.doi.org/10.1590/S000137652000000200009.

Gorini, C., Haq, B.U., dos Reis, A.T., Silva, C.G., Cruz, A., Soares, E., Grangeon, D., 2014. Late Neogene sequence stratigraphic evolution of the Foz do Amazonas Basin, Brazil. Terra Nova 26, 179-185. http://dx.doi.org/10.1111/ter.12083.

Govin, A., Chiessi, C.M., Zabel, M., Sawakuchi, A.O., Heslop, D., Hörner, T., Zhang, Y., Mulitza, S., 2014. Terrigenous input off northern South America driven by changes in Amazonian climate and the North Brazil Current retroflection during the last $250 \mathrm{ka}$. Clim. Past 10, 843-862. http://dx.doi.org/10.5194/cp-10-8432014.

Gradstein, F.M., Ogg, J.G., Schmitz, M., 2012. The Geologic Time Scale 2012. 2-Volume Set. Elsevier.

Hammer, Ø., Harper, D.A.T., Ryan, P.D., 2001. PAST: paleontological statistics software: package for education and data analysis. Palaeontol. Electronica 4, 1-9.

Heinrich, S., Zonneveld, K.A.F., 2013. Influence of the Amazon River development and constriction of the Central American Seaway on Middle/Late Miocene oceanic conditions at the Ceara Rise. Palaeogeogr. Palaeoclimatol. Palaeoecol. 386, 599-606. http://dx.doi.org/10.1016/j.palaeo.2013.06.026.

Hoorn, C., Guerrero, J., Sarmiento, G.A., Lorente, M.A., 1995. Andean tectonics as a cause for changing drainage patterns in Miocene northern South America. Geology 23, 237-240. http://dx.doi.org/10.1130/00917613(1995)023<0237: ATAACF>2.3.CO;2.

Hopmans, E.C., Schouten, S., Sinninghe Damsté, J.S., 2016. The effect of improved chromatography on GDGTbased palaeoproxies. Org. Geochem. 93, 1-6. http:// dx.doi.org/10.1016/j.orggeochem.2015.12.006.

Hopmans, E.C., Weijers, J.W.H., Schefuß, E., Herfort, L., Sinninghe Damsté, J.S., Schouten, S., 2004. A novel proxy for terrestrial organic matter in sediments based on branched and isoprenoid tetraether lipids. Earth Planet. Sci. Lett. 224, 107-116. http://dx.doi.org/10.1016/j.eps1.2004.05.012. 
Horbe, A.M.C., Motta, M.B., de Almeida, C.M., Dantas, E.L., Vieira, L.C., 2013. Provenance of Pliocene and recent sedimentary deposits in western Amazônia, Brazil: consequences for the paleodrainage of the Solimões-Amazonas River. Sediment. Geol. 296, 9-20. http://dx.doi.org/10.1016/j.sedgeo.2013.07.007.

Kim, J.-H., Zell, C., Moreira-Turcq, P., Pérez, M.A.P., Abril, G., Mortillaro, J.-M., Weijers, J.W.H., Meziane, T., Sinninghe Damsté, J.S., 2012. Tracing soil organic carbon in the lower Amazon River and its tributaries using GDGT distributions and bulk organic matter properties. Geochim. Cosmochim. Acta 90, 163-180. http:// dx.doi.org/10.1016/j.gca.2012.05.014.

Kumar, N., Embley, R.W., 1977. Evolution and origin of Ceará Rise: an aseismic rise in the western equatorial Atlantic. Geol. Soc. Am. Bull. 88, 683-694. http:// dx.doi.org/10.1130/00167606(1977) $88<683:$ EAOOCR $>2.0 . C O ; 2$.

Mcdaniel, D.K., Mclennan, S.M., Hanson, G.N., 1997. Provenance of Amazon fan muds: constraints from Nd and $\mathrm{Pb}$ isotopes. Proc. Ocean Drill. Program Sci. Results 155, 169-176.

McLennan, S.M., Hemming, S., McDaniel, D.K., Hanson, G.N., 1993. Geochemical approaches to sedimentation, provenance, and tectonics. Spec. Pap., Geol. Soc. Am. 284, 21-40. http://dx.doi.org/10.1130/SPE284-p21.

Mora, A., Baby, P., Roddaz, M., Parra, M., Brusset, S., Hermoza, W., Espurt, N., 2010. Tectonic history of the Andes and sub-Andean zones: implications for the development of the Amazon Drainage Basin. In: Hoorn, C., Wesselingh, F.P. (Eds.), Amazonia: Landscape and Species Evolution. Wiley-Blackwell Publishing Ltd., pp. 38-60.

Mora, A., Reyes-Harker, A., Rodriguez, G., Tesón, E., Ramirez-Arias, J.C., Parra, M., Caballero, V., Mora, J.P., Quintero, I., Valencia, V., Ibañez, M., Horton, B.K., Stockli, D.F., 2013. Inversion tectonics under increasing rates of shortening and sedimentation: cenozoic example from the Eastern Cordillera of Colombia. Geol. Soc. (Lond.) Spec. Publ. 377, 411-442. http://dx.doi.org/10.1144/SP377.6.

Nie, J., Horton, B.K., Saylor, J.E., Mora, A., Mange, M., Garzione, C.N., Basu, A., Moreno, C.J., Caballero, V., Parra, M., 2012. Integrated provenance analysis of a convergent retroarc foreland system: $\mathrm{U}-\mathrm{Pb}$ ages, heavy minerals, $\mathrm{Nd}$ isotopes, and sandstone compositions of the Middle Magdalena Valley basin, northern Andes, Colombia. Earth-Sci. Rev. 110, 111-126. http://dx.doi.org/10.1016/j.earscirev.2011.11.002.

Nisancioglu, K.H., Raymo, M.E., Stone, P.H., 2003. Reorganization of Miocene deep water circulation in response to the shoaling of the Central American Seaway. Paleoceanography 18, 1006. http://dx.doi.org/10.1029/2002PA000767.

Ohkouchi, N., Wado, E., 1997. In: Shackleton, N.J., Curry, W.B., Richter, C., Bralower, T.J. (Eds.), Secular Variations in Sedimentary Organic $\delta 13 \mathrm{C}$ During the Last 35 M.y. the Tropical Atlantic, Site 925, pp. 501505. Oncken, O., Hindle, D., Kley, J., Elger, K., Victor, P., Schemmann, K., 2006. Deformation of the Central Andean Upper Plate system - facts, fiction, and constraints for plateau models. In: Oncken, O., Chong, G., Franz, G., Giese, P., Götze, H.-J., Ramos, V.A., Strecker, M.R., Wigger, P. (Eds.), The Andes, Frontiers in Earth Sciences. Springer, Berlin, Heidelberg, pp. 3-27.

Peterse, F., Kim, J.-H., Schouten, S., Kristensen, D.K., Koç, N., Sinninghe Damsté, J.S., 2009. Constraints on the application of the MBT/CBT palaeothermometer at high latitude environments (Svalbard, Norway). Org. Geochem. 40, 692-699. http:// dx.doi.org/10.1016/j.orggeochem.2009.03.004.

Powers, L.A., Werne, J.P., Johnson, T.C., Hopmans, E.C., Damsté, J.S.S., Schouten, S., 2004. Crenarchaeotal membrane lipids in lake sediments: a new paleotemperature proxy for continental paleoclimate reconstruction? Geology 32, 613-616. http://dx.doi.org/10.1130/G20434.1.

Prahl, F.G., De Lange, G.J., Scholten, S., Cowie, G.L., 1997. A case of post-depositional aerobic degradation of terrestrial organic matter in turbidite deposits from the Madeira Abyssal Plain. In: Organic Geochemistry of Paleoclimatic Markers: Production, Preservation and Modeling. Org. Geochem. 27, 141-152. http:// dx.doi.org/10.1016/S0146-6380(97)00078-8.

Roddaz, M., Baby, P., Brusset, S., Hermoza, W., Maria Darrozes, J., 2005a. Forebulge dynamics and environmental control in Western Amazonia: the case study of the Arch of Iquitos (Peru). Tectonophysics 399, 87-108. http://dx.doi.org/ 10.1016/j.tecto.2004.12.017.

Roddaz, M., Viers, J., Brusset, S., Baby, P., Hérail, G., 2005b. Sediment provenances and drainage evolution of the Neogene Amazonian foreland basin. Earth Planet. Sci. Lett. 239, 57-78. http://dx.doi.org/10.1016/j.epsl.2005.08.007.

Roddaz, M., Viers, J., Moreira-Turcq, P., Blondel, C., Sondag, F., Guyot, J.-L., Moreira, L., 2014. Evidence for the control of the geochemistry of Amazonian floodplain sediments by stratification of suspended sediments in the Amazon. Chem. Geol. 387, 101-110. http://dx.doi.org/10.1016/j.chemgeo.2014.07.022. Sinninghe Damsté, J.S., 2016. Spatial heterogeneity of sources of branched tetraethers in shelf systems: the geochemistry of tetraethers in the Berau River delta (Kalimantan, Indonesia). Geochim. Cosmochim. Acta 186, 13-31. http:// dx.doi.org/10.1016/j.gca.2016.04.033.

Sinninghe Damsté, J.S., Schouten, S., Hopmans, E.C., van Duin, A.C.T., Geenevasen, J.A.J., 2002. Crenarchaeol the characteristic core glycerol dibiphytanyl glycerol tetraether membrane lipid of cosmopolitan pelagic 
crenarchaeota. J. Lipid Res. 43, 1641-1651. http://dx.doi.org/10.1194/j1r.M200148-JLR200. Stewart, J.A., Gutjahr, M., James, R.H., Anand, P., Wilson, P.A., 2016. Influence of the Amazon River on the Nd isotope composition of deep water in the western equatorial Atlantic during the Oligocene-Miocene transition. Earth Planet. Sci. Lett. 454, 132-141. http://dx.doi.org/10.1016/j.epsl.2016.08.037.

Tierney, J.E., Russell, J.M., Eggermont, H., Hopmans, E.C., Verschuren, D., Sinninghe Damsté, J.S., 2010. Environmental controls on branched tetraether lipid distributions in tropical East African lake sediments. Geochim. Cosmochim. Acta 74, 4902-4918. http://dx.doi.org/10.1016/j.gca.2010.06.002.

Viers, J., Roddaz, M., Filizola, N., Guyot, J.-L., Sondag, F., Brunet, P., Zouiten, C., Boucayrand, C., Martin, F., Boaventura, G.R., 2008. Seasonal and provenance controls on Nd-Sr isotopic compositions of Amazon rivers suspended sediments and implications for $\mathrm{Nd}$ and $\mathrm{Sr}$ fluxes exported to the Atlantic Ocean. Earth Planet. Sci. Lett. 274, 511-523. http://dx.doi.org/10.1016/j.eps1.2008.08.011.

Weijers, J.W.H., Schouten, S., van den Donker, J.C., Hopmans, E.C., Sinninghe Damsté, J.S., 2007. Environmental controls on bacterial tetraether membrane lipid distribution in soils. Geochim. Cosmochim. Acta 71, 703-713. http://dx.doi.org/ 10.1016/j.gca.2006.10.003.

Yu, H., Chin, M., Yuan, T., Bian, H., Remer, L.A., Prospero, J.M., Omar, A., Winker, D., Yang, Y., Zhang, Y., Zhang, Z., Zhao, C., 2015. The fertilizing role of African dust in the Amazon rainforest: a first multiyear assessment based on data from Cloud-Aerosol Lidar and Infrared Pathfinder Satellite Observations. Geophys. Res. Lett. 42, 2015GL063040. http://dx.doi.org/10.1002/2015GL063040.

Zell, C., Kim, J.-H., Abril, G., Sobrinho, R.L., Dorhout, D., Moreira-Turcq, P., Sinninghe Damste, J.S., $2013 \mathrm{a}$. Impact of seasonal hydrological variation on the distributions of tetraether lipids along the Amazon River in the central Amazon basin: implications for the MBT/CBT paleothermometer and the BIT index. Front. Microbiol. 4. http://dx.doi.org/10.3389/fmicb.2013.00228.

Zell, C., Kim, J.-H., Moreira-Turcq, P., Abril, G., Hopmans, E.C., Bonnet, M.-P., Sobrinho, R.L., Damste, J.S.S., 2013b. Disentangling the origins of branched tetraether lipids and crenarchaeol in the lower Amazon River: implications for GDGT-based proxies. Limnol. Oceanogr. 58, 343-353. http://dx.doi.org/10.4319/1o.2013.58.1.0343.

Zell, C., Kim, J.-H., Hollander, D., Lorenzoni, L., Baker, P., Silva, C.G., Nittrouer, C., Sinninghe Damsté, J.S., 2014. Sources and distributions of branched and isoprenoid tetraether lipids on the Amazon shelf and fan: implications for the use of GDGTbased proxies in marine sediments. Geochim. Cosmochim. Acta 139, 293312. http://dx.doi.org/10.1016/j.gca.2014.04.038. 
Fig. 1. Map of South America showing the drainage network the northern part of South America, with the Orinoco (1) and the tributaries of the Amazon (2. Solimões and tributaries, 3. Negro, 4. Trombetas, 5. Madeira, 6. Tapajós, 7. Xingu, 8. Araguaia and Tocantins). The main sediment provinces for riverine particulate matter indicated (adapted from Cordani and Sato, 1999). The inset shows the location of Ceará Rise, the topographic high on the abyssal western South Atlantic in front of the Amazon River, the coastal bathymetry and the location of site 925 (ODP Leg 154) (after Curry et al., 1995).

Caribbean Sea

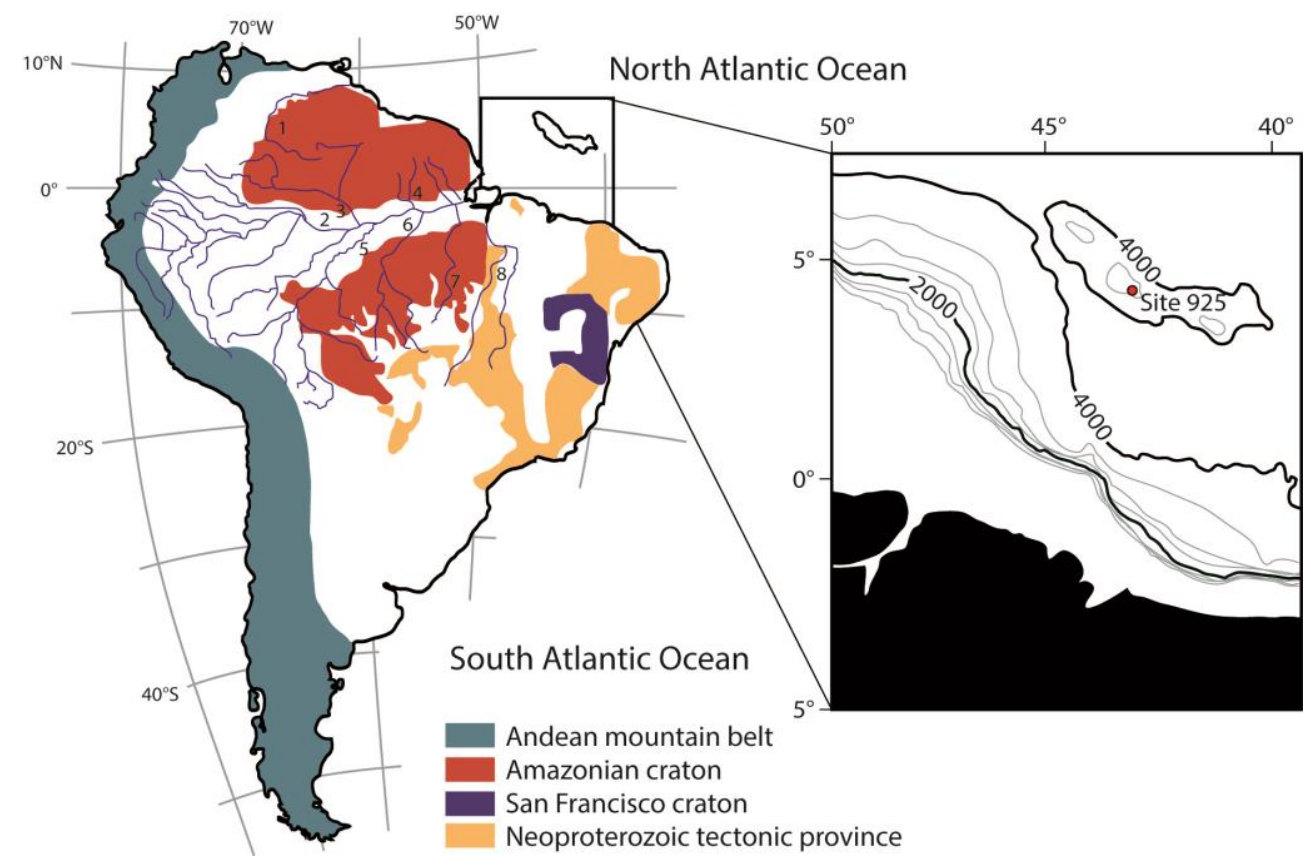


Fig. 2. Sedimentary and provenance data. The main clusters are indicated, as are important changes in accumulation rates and sediment provenance (horizontal dashed lines). TAR $=$ terrigenous mass accumulation rates.

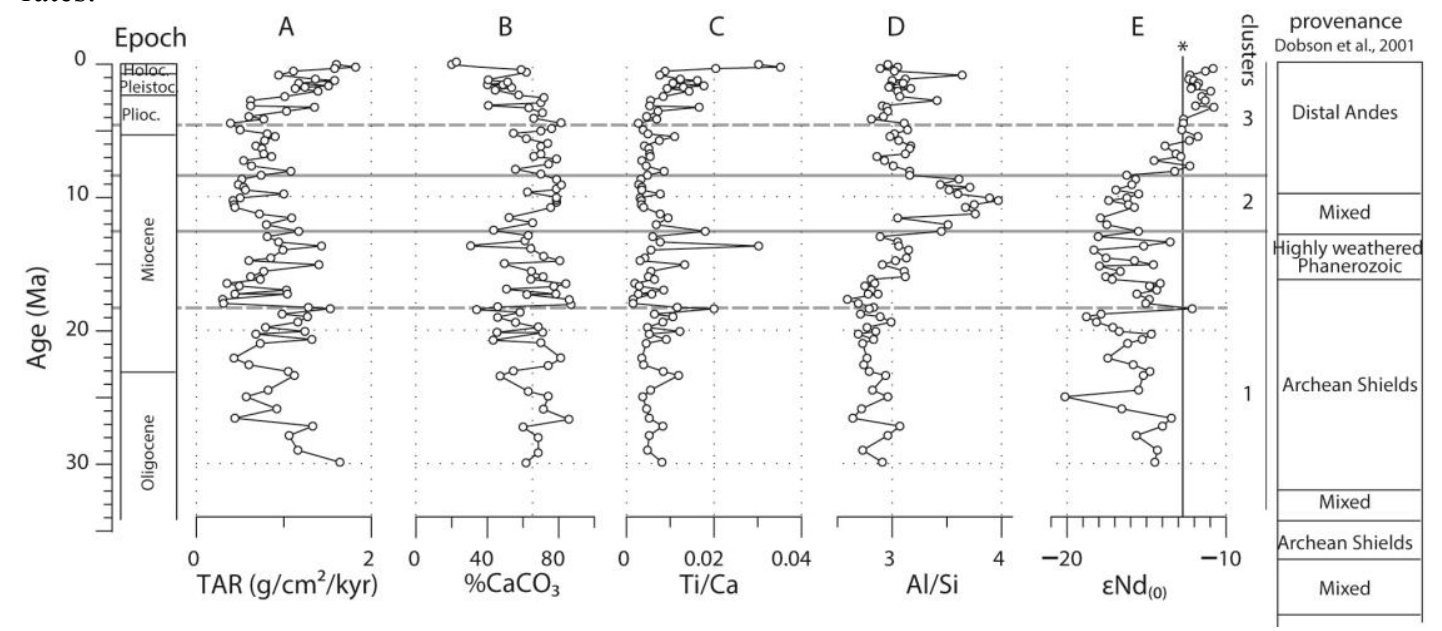


Fig. 3. Bulk organic properties and lipid concentrations and ratios in sediments from Ceará Rise. BIT is the branched and isoprenoid index of GDGTs (Hopmans et al., 2004). \%tetra is the relative abundance of tetramethylated brGDGTs and \#ringstetra is the weighted average number of cyclopentane structures (after Sinninghe Damsté, 2016). Horizontal lines indicate the three clusters based on clustering of XRF data (see also Fig. 4). Horizontal dashed lines indicate important changes in the organic matter provenance.

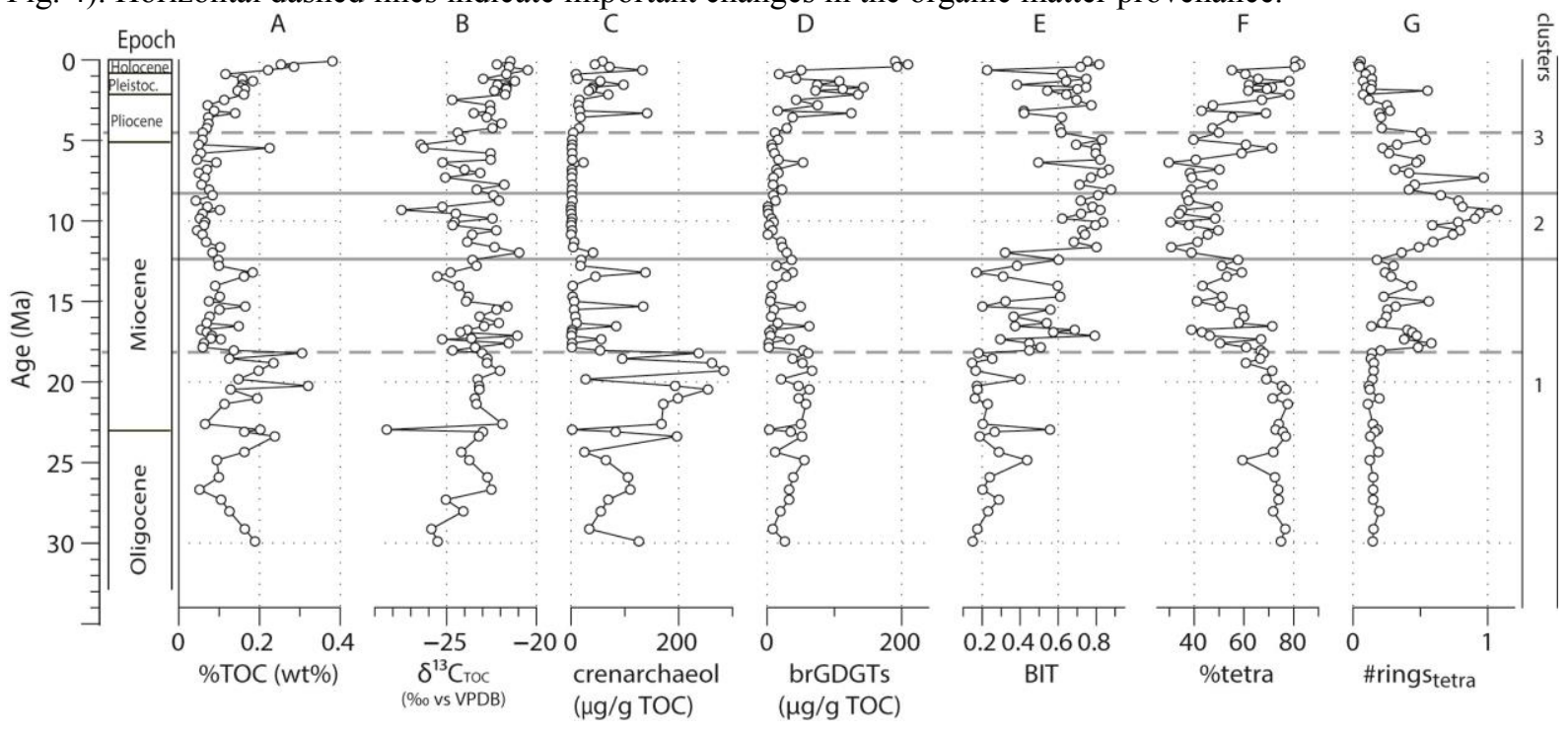


Fig. 4. Sources of terrigenous matter compared to core 925 on Ceará Rise (adapted from Govin et al., 2014). Data for suspended particles in Rio Negro from Govin et al. (2014), Rio Solimões and Madeira from Bouchez et al. (2011) and Sahara dust particles from Collins et al. (2013).

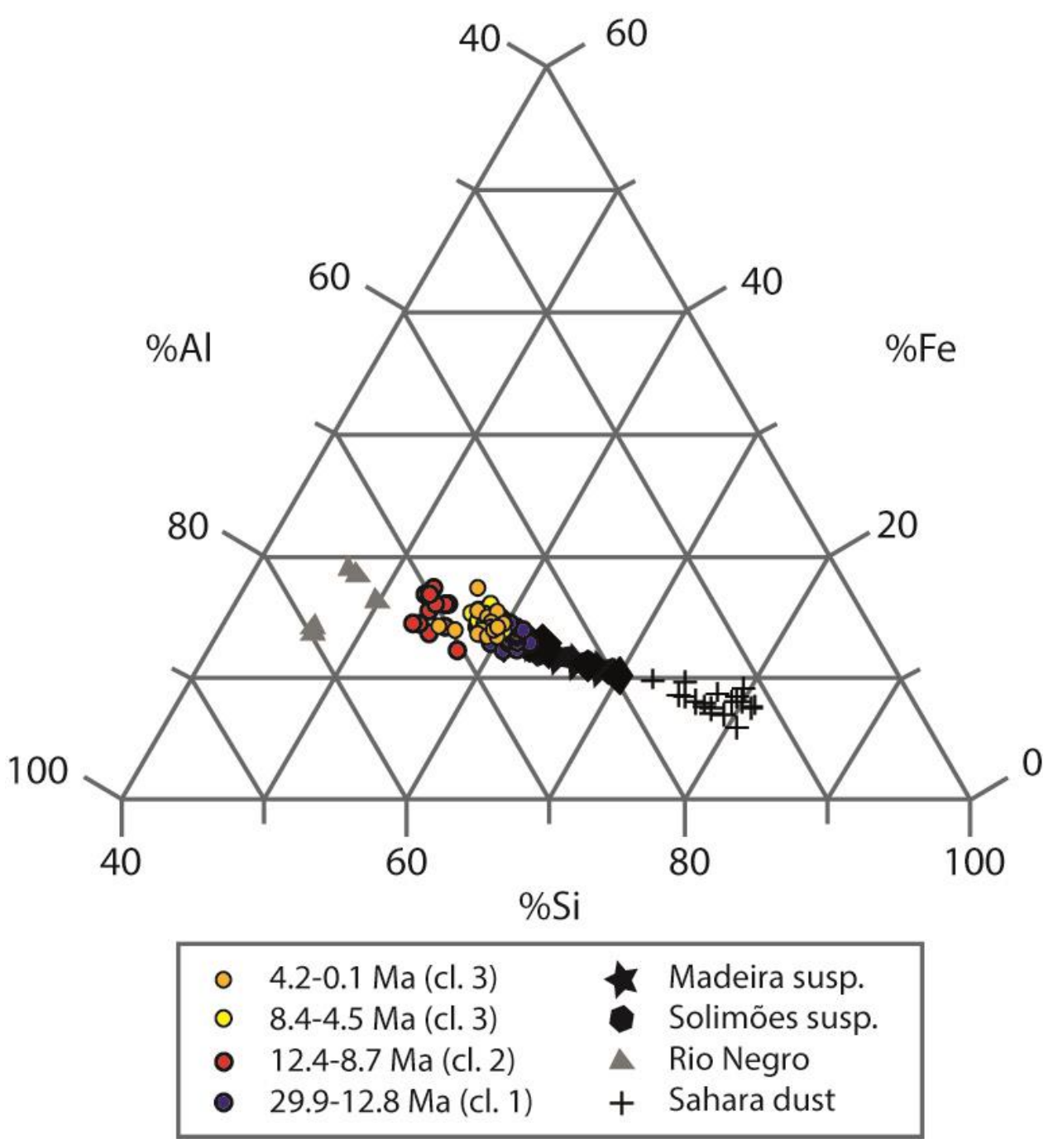


Fig. 5. Cross plot showing (A) $\varepsilon \mathrm{Nd}(0)$ versus $\mathrm{Al} / \mathrm{Si}$ ratio's and $(\mathrm{B}) \varepsilon \mathrm{Nd}(0)$ versus $\mathrm{fSm} / \mathrm{Nd}$ (fractional deviation of $147 \mathrm{Sm} / 144 \mathrm{Nd}$ from CHUR (CHondritic Uniform Reservoir)). Different colored circles indicate the different clusters or core sections based on XRF data clustering (paragraph 5.1 Provenance). Figure (B) also shows values for South American cratonic rocks, Andean igneous rocks, Andean foreland basin sediment, Amazon River sediment (after Mcdaniel et al., 1997 and data references therein). Data from modern Solimões suspended sediments (hexagons) and Madeira (stars) river suspended matter are after Bouchez et al. (2011) and Viers et al. (2008), Amazon floodplain data after Roddaz et al. (2014) and Amazon and Congo River mouth after Bayon et al. (2015). Vertical dashed line indicates the cutoff value separating sediment with and Andean provenance from cratonic provenance (after Nie et al., 2012). (For interpretation of the references to color in this figure legend, the reader is referred to the web version of this article.)
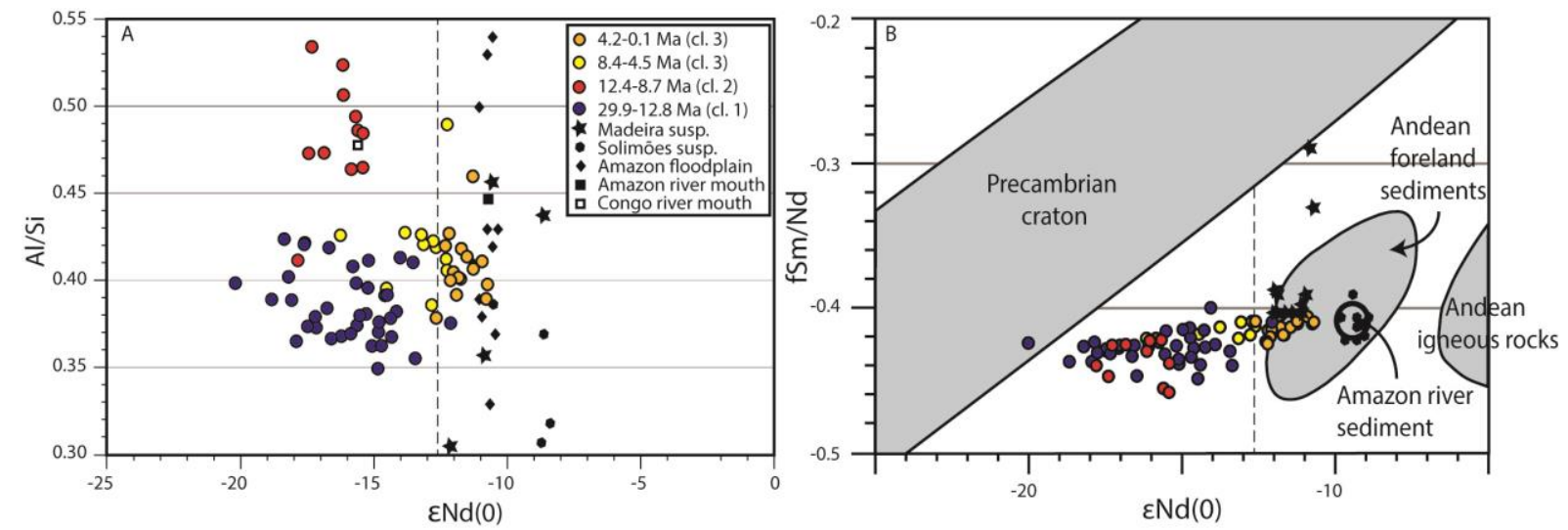
Fig. 6. Figure summarizing the main changes in sediment and organic matter sources. On the right hand side of the figure are events indicates with arrows. Data after 1) Horbe et al. (2013), 2) Roddaz et al. (2005a), 3) Dobson et al. (2001), 4) Gorini et al. (2014), 5) Heinrich and Zonneveld (2013) and 6) Bayon et al. (2015).

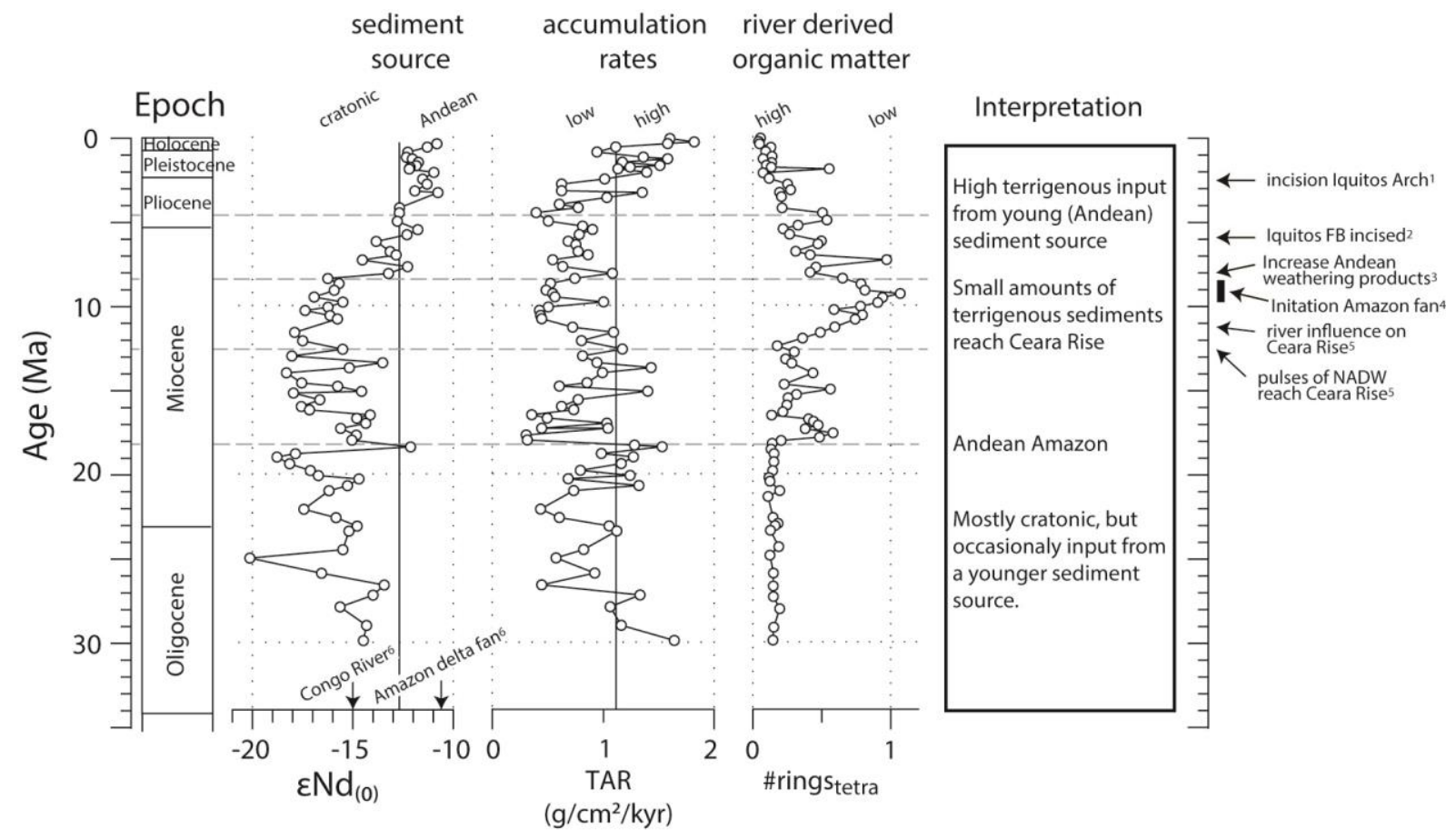

